Article

\title{
Fiber-Reinforced Polymer Nets for Strengthening Lava Stone Masonries in Historical Buildings
}

\author{
Santi Maria Cascone ${ }^{1}$, Vincenzo Sapienza ${ }^{1, *}$, Irene Lionti ${ }^{1}$ and Simona Maria Carmela Porto ${ }^{2}$ \\ 1 Department of Civil Engineering and Architecture, University of Catania, S. Sofia n ${ }^{\circ}$ 64, Catania 95123, Italy; \\ scascone@dau.unict.it (S.M.C.); irene.lionti@gmail.com (I.L.) \\ 2 Department of Agriculture, Food and Environment, University of Catania, S. Sofia $n^{\circ} 100$, Catania 95123, \\ Italy; siporto@unict.it \\ * Correspondence: vsapienza@unict.it; Tel.: +39-320-1803401
}

Academic Editor: Marc A. Rosen

Received: 26 February 2016; Accepted: 8 April 2016; Published: 21 April 2016

\begin{abstract}
The strengthening of masonries is a crucial step in building restoration works because of its relevance, mostly with regard to the improvement of building seismic behavior. Current building technologies are based on the use of steel nets which are incorporated into cement plasters. The use of steel has a number of contraindications that can be solved by using composite materials such as glass fiber nets, which have high mechanical characteristics and lightness, elasticity, corrosion resistance, and compatibility with lime plaster. Building interventions, that take into account the application of glass fiber nets, are very sustainable from several points of view, e.g., material production, in situ works, economic cost and durability. In Italy, several experiments have been carried out in situ with the aim of testing the mechanical characteristics of masonries which have been treated with fiber-reinforced polymer (FRP) nets. This paper deals with a series of in situ tests carried out during the restoration works of an important historical building located in Catania (Sicily, Italy). The results achieved are largely positive.
\end{abstract}

Keywords: composite materials; Cultural Heritage; anti-seismic improvement; experimental tests

\section{Introduction}

Italian architectural heritage is one of the richest and largest in the world, and it represents an enormous resource that must be safeguarded and preserved in order to be passed on to future generations [1,2]. Commonly, historical buildings, which form part of the architectural heritage, are used for social services that require high quality standards achieved by constant activities of maintenance. Moreover, since these buildings are highly exposed to the seismic risk related to the vulnerability of a large part of the European and Italian territory [3], interventions aimed at improving or adapting these types of buildings to the regulatory standards are required in order to preserve them from earthquakes.

As largely debated in literature [4-7], traditional building techniques and materials are generally not suitable for reaching proper anti-seismic safety in historical structures [6] because of several issues such as the mechanical characteristics of the building materials and their damage mechanisms [8,9]. Consequently, to avoid possible conflicts between building conservation criteria and anti-seismic requirements, it is often necessary to apply "seismic improvement" instead of "seismic upgrade"; thus, an anti-seismic protection level, lower than that required for buildings built by using reinforced concrete or steel structures, is accepted by the regulatory standards. For each limit state, the improvement effectiveness must be quantified, evaluating the Peak Ground Acceleration (PGA) levels generating local collapse mechanisms, before and after the interventions [10]. 
Therefore, some research studies are directed towards the use of contemporary building materials and techniques (e.g., base isolation, energy dissipation, shape-memory alloy devices, and FRP materials) that could be acceptable for reducing the seismic vulnerability of historical buildings if philologically correct, i.e., if it produces compatible and reversible building interventions. In this context, the use of fiber-reinforced materials is one of the most promising methods because it makes it possible to obtain adequate levels of security without employing electro-welded steel meshes which were widely used after earthquakes in the past, especially in the second half of the 20th century in Italy [11]. The use of FRP materials started more than a decade ago and research studies are still in progress, especially with regard to new material families [12]. One of the most appreciated characteristics of the fiber-reinforced materials is the sustainability of its production and usage [13,14].

The results discussed in this paper derive from a series of tests carried out on lava stone masonries of the Asilo Sant'Agata (Figure 1), an ancient building for elderly care which was built in Catania (Sicily, Italy) at the end of the 19th century [15]. Since the tested masonries are quite recurrent in coeval buildings, especially in the eastern part of Sicily [16], the results are very useful for achieving improvement of the seismic behavior of historical buildings.

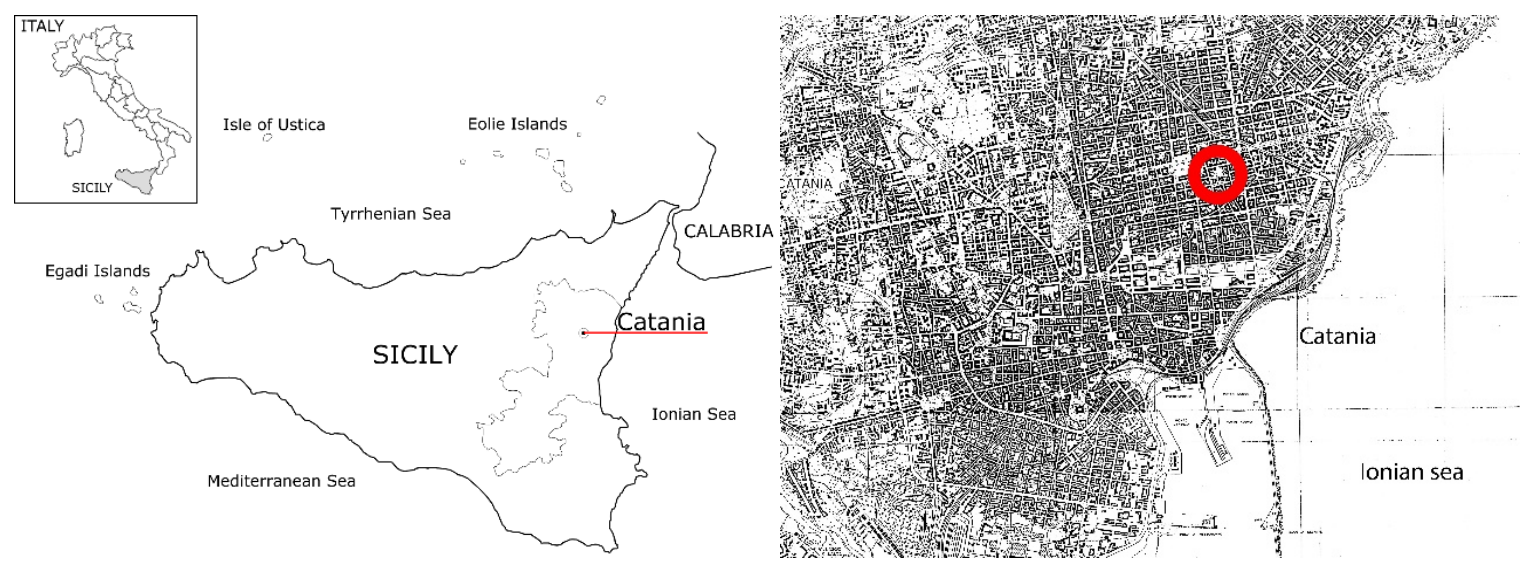

Figure 1. Location of the "Asilo Sant'Agata" of Catania (Sicily, Italy).

\section{The Consolidation Intervention by Using Glass Fiber}

Composite materials are obtained from the combination of two or more base materials of different nature whose adhesion is guaranteed by an interface. They have the advantage of matching the performance of both its components to obtain a final product with better performance than that obtained by using each element separately [17]. Generally, a composite material consists of three components: the matrix, which is weak and continuous, the reinforcement, which is strong and hard, and the interface, which guarantees the compatibility and adhesion between the other two components. The reinforcement is a set of fibers, which could be assembled in various ways, according to the intended use; the matrix, which is spread on these fibers, has the role of protecting the reinforcement and transferring to it the stresses, uniformly. Generally, the fibers are assembled into fabrics that, from a geometric point of view, are essentially divided in the following ways: unidirectional fabrics, made from fibers that are arranged in a parallel manner in the direction of their length; bi-directional fabrics, made from fibers that are arranged according to two orthogonal directions; multi-axial fabrics, obtained by placing the fibers in various directions on the plane. Usually, the matrix is constituted by thermosetting epoxy resins that are obtained by combining a main reagent, which is the epoxy pre-polymer (a viscous fluid), with a cross-linking agent [17].

Among composite materials, fiber-reinforced polymers (FRP) are widely used in the building industry; in FRP, the reinforcement is typically made by alkali-resistant glass fibers, stranded to create a monolithic, flexible and resistant mesh in all directions, while the matrix is made of thermosetting polymeric resins which impregnate the mesh. 
The FRP are characterized by high mechanical resistance, fire resistance, chemical inertia, water resistance, a low coefficient of thermal expansion, and high compatibility with other resins. They are nonmagnetic, do not give rise to harmful emissions and have a low thermal and acoustic transmittance. Finally, they have a low embodied energy [18-20].

They are used in many building interventions such as in the reinforcement of concrete beds and floors, in the stiffening of insulating screeds, in concrete elements with small thickness, and in reinforced masonry. Thanks to the proprieties of the base materials [21], this kind of intervention can be considered very sustainable from several points of view such as material production, in situ works, and economic cost and durability.

Among the interesting applications of FPR, the possibility to create a net for the strengthening of masonries is relevant with regard to the consolidation of historical buildings [22]. In this kind of intervention, the net is placed on the existing structure, after the removal of the plaster, and steadily attached by connectors made of the same composite material. The connectors pass through the masonry and are bent on the opposite side to be locked. Everything is covered by a new finishing layer, generally obtained with lime mortar plaster. The intervention can be done in all building elements (e.g., architraves, arches, splays, pillars, and vaults) $[23,24]$.

In the recent past, the consolidation of masonry buildings was done using electro-welded steel nets, covered with a layer of cement plaster. In comparison to this kind of building intervention, the use of FRP materials allows the achievement of many advantages:

- oxidation resistance of glass fibers;

- compatibility of the lime mortars with the historical walls;

- reduced thickness of the mesh, which allows the optimal positioning of the net in the original structures;

- non-magnetic property which avoids any interference problems with electro-magnetic fields;

- low maintenance requirements.

\section{Materials and Methods}

\subsection{The Historical Building Object of the Research Study}

The study was carried out in the "Asilo Sant'Agata", one of the most appreciated charitable institutions of Catania, a medium city on the eastern coast of Sicily (Italy), near the Etna Volcano. According to the documentation obtained from historical archives, the building was designed by Carmelo Sciuto-Patti [25], its construction started in 1878 and it was inaugurated on 10 June 1883. The structure was built by the "Congregation of Little Sisters of Poors", which provided assistance to needy elderly people, and it still belongs to this congregation today. The congregation, which was founded in France by Jeanne Jugan (Cancale, 25 October 1792-La Tour Saint-Joseph, St. Pern 29 August 1879), is present in 32 countries all over the world.

The building is composed of a small number of regular volumes which are centered on the elegant neo-Gothic church, which represents the fulcrum of the whole complex. Two almost symmetric wings (the east and west one) form the building; they contain the accommodations for the elderly and related services (Figure 2).

The original structure had a basement and two stories above ground level. The floor of the second story was $6 \mathrm{~m}$ above the ground. Subsequent changes have led to the realization of two mezzanines which subdivided the story height and transformed the pitched roofs in the terraces. The façades are done in the neoclassical style, according to the typical architectonic language of those years [26]. The original bearing structure (vertical walls and real vaults) is made of squared stone lava masonry, while the added slabs are in the steel beams.

From a structural point of view, the building was not done in accordance with the current law concerning the anti-seismic regulations [27]. Therefore, since 1999, the old asylum and services to the elderly were suspended. 


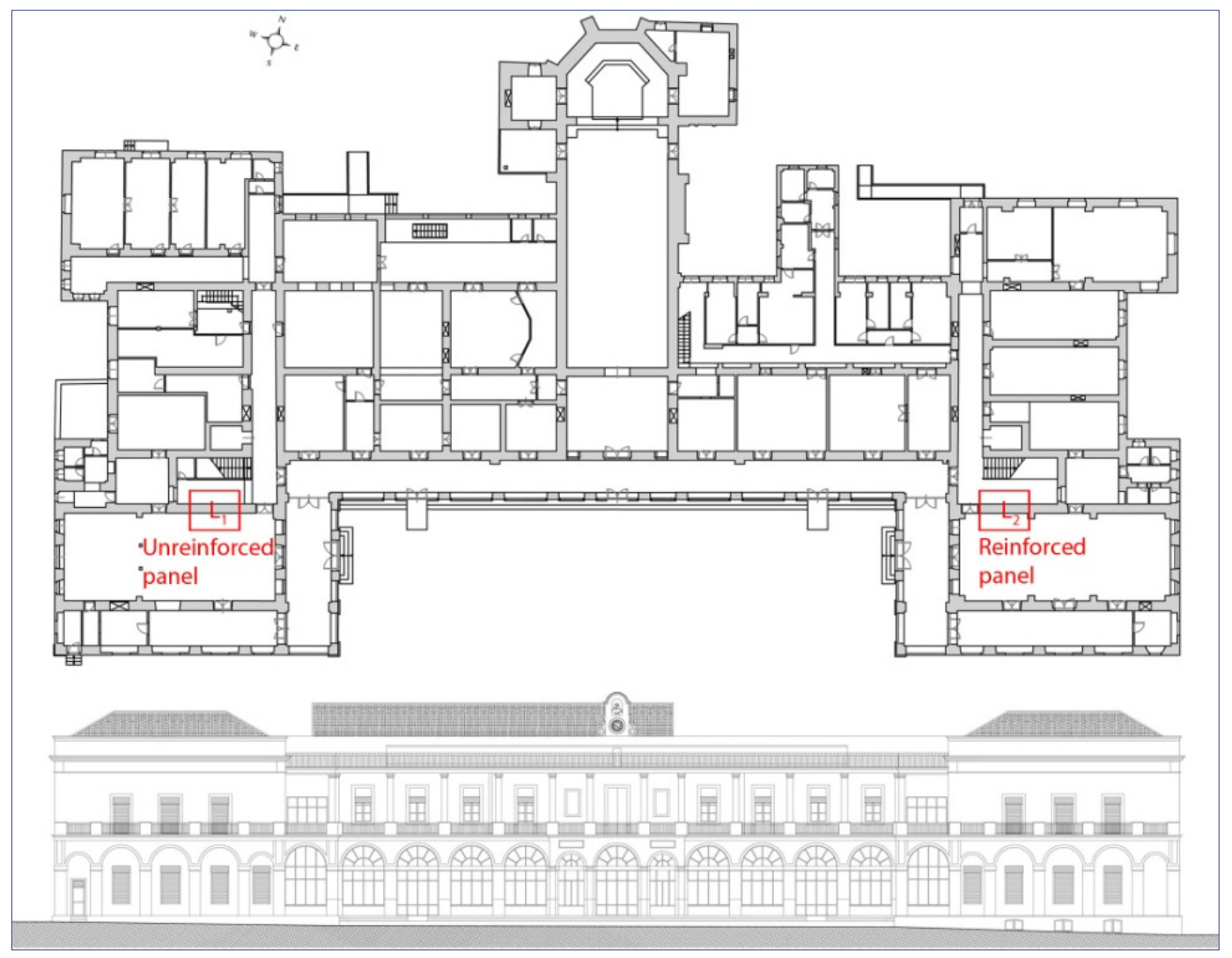

Figure 2. Plant and façade of the current status with location of the tests.

In 2008, the "Congregation of Little Sisters of Poors" planned the restructuring of the nursing home, in order to bring the building back to its original function. At the same time, they would like to renew and adapt the building to the current standards of care and safety. The project also included important interventions such as the static improvement of the bearing structures constituted by lava stone masonry. As recommended in the Italian current technical regulation (NCT 2008), it was developed in a push-over analysis, by realizing a tridimensional model of the building. The interventions were designed in full respect to the historical, artistic, cultural and spiritual values of the architectural building complex. Thanks to an accurate survey of geometry and materials, the confidence factor was set at 1.2.

The structural intervention has been designed and realized by using FRP nets and lime mortar plaster. Some preliminary tasks were necessary for the execution of the works, such as the disposal of existing finishing, the removal of masonry joints by hand tools, and the washing of the wall with low pressure sprayed water; these phases were followed by the pose of the glass fiber net $(66 \mathrm{~mm} \times 66 \mathrm{~mm})$, anchored with connectors and further secured by the layer of lime plaster, with anti-shrinkage additives (Figure 3).

Such suggested technology has been tested in the building in situ thanks to accurate tests, described in the following section. 

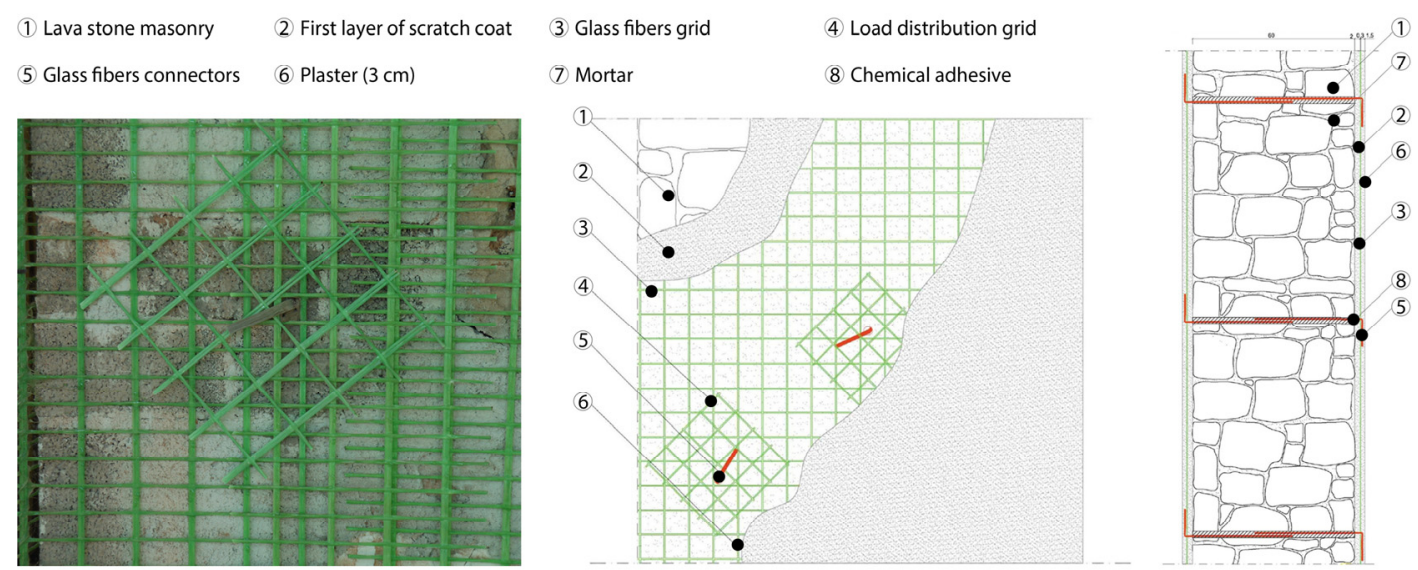

Figure 3. Consolidation with FRP nets.

\subsection{Test Methodology}

To evaluate the effectiveness of the described consolidation technique on lava stone masonries, a diagonal compression test $[7,28]$ was performed in situ. It involved the application of a diagonal pressure load on an almost square-shaped piece of masonry panel until its breakage. This type of test required specifications for the determination of the shear resistance for a cracking diagonal: theoretically, this method of application of the load produces, indeed, a state of stress-strain similar to the one resulting from the shear resistance, and determines the breakage of the panel along the compression isostatic lines.

In the laboratory, the test was codified by the ASTM E 519-02 norm; in situ, unlike in the laboratory, the panel was obtained from a portion of an existing wall that was cut with a diamond-cut saw, leaving the panel partially stuck to the existing wall. In detail, "the diagonal compression test allows the under-load panel a free-moving deformation, because its four sides are free from any constraint, with the exception of a small portion of masonry which remains connected to the remaining part of the building. This connection is irrelevant, as shown by some numerical processing" [29].

It was necessary to carry out a double test; the first one was carried out on the masonry wall in its original condition and the second one on the consolidated wall, so that the increase in resistance was appreciated. The chosen type of masonry consisted of blocks of squared lava stones which were positioned forming pseudo-isodomic courses; the blocks were placed by using lime mortar and ghiara, which is a red pozzolanic local inert material [26]. To stabilize the laying beds and to guarantee mutual contrast, stone flakes and terracotta fragments were used. The masonry was strengthened with the systematic use of diatones. This equipment could have positive feedback not only for the considered building, but in most of the structures built between the second half of the 19th century and the first decades of the following century in the whole Etna area [30]. This kind of masonry is known by the name of Muratura Rinzeppata [31]. By considering the destructive aspect of the test, as well as the heavy equipment required, stone masonry samples were located upon two walls intended to be demolished in order to realize two doors, placed on the ground floor, in opposite wings of the building (Figure 2).

To allow the correct positioning of the testing tools in the opposing corners, the chosen masonries were detached from the wall. A manual hydraulic jack was used to apply the load, so that it can be gradually dosed (Figure 4). The applied load was measured with a pressure transducer, while the relative displacements of the diagonal points of the sample were measured by pairs of potentiometric transducers, placed in both faces. All equipment was connected to an electronic purchasing interfaced with a computer. 

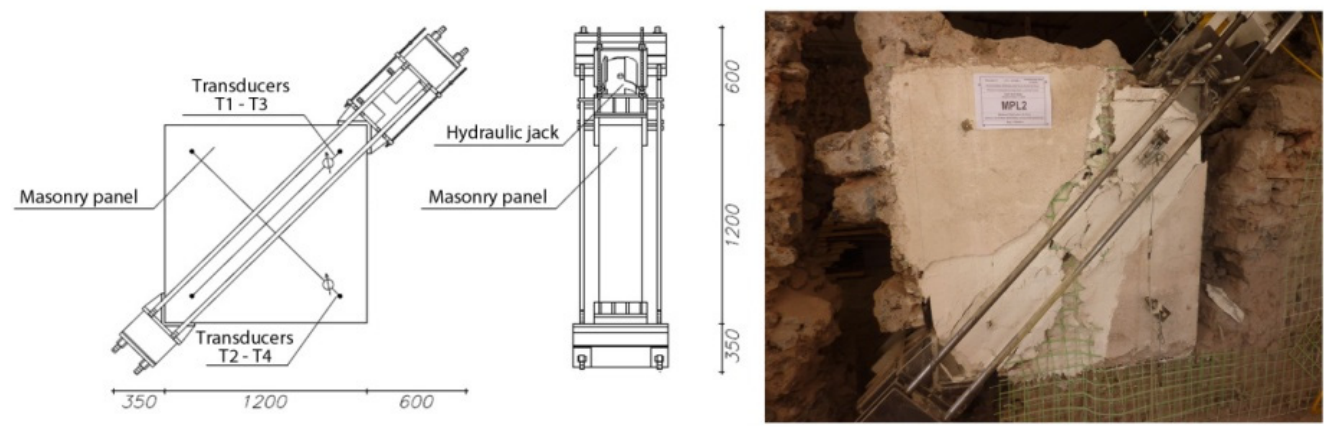

Figure 4. Diagram of the test.

During the test the applied load, the lengthening and the shortening of the bases were measured. As it is known, it is possible to derive the equivalent principal tension of traction by the mean traction deformation in the direction perpendicular to the compressed diagonal. In detail, the test was carried out according to the recommendations of the RILEM 1931. Another method used is that indicated by the ASTM E 519-02.

The loading procedure was characterized by a sequence of loading-unloading-reloading cycles with an amplitude of about $10-15 \mathrm{kN}$ up to the peak value of the resistance. It proceeded with constant speed in both phases, equal to approximately $1.2 \mathrm{kN} / \mathrm{s}$. After the peak resistance, the tests were conducted monotonously and with displacement control. The experiments were completed when the compressed diagonal contraction reached a value close to $20 \mathrm{~mm}$.

For the mechanical characterization of the mortar used for the jacket, laboratory tests were also carried out by simple compression and indirect traction (tensile strength test); Young's modulus and Poisson's coefficient were also evaluated (the tests were performed in a laboratory office of evidence and materials, on cylindrical samples realized in the pipeline, with 28 days of curing).

\section{Results and Discussion}

The first test carried out concerned the wall panel in the original condition (the test was carried out in situ on 16 May 2013). The sample was almost square-shaped, with a side of about $120 \mathrm{~cm}$ and a thickness of $60 \mathrm{~cm}$. Before applying the load, the wall appeared in an acceptable condition, without visible cracks or alterations.

During the test, the load-deformation diagram was plotted (Figure 5a) and at the end it was possible to evaluate the load diagonal maximum $\left(\mathrm{P}_{\max }=83.10 \mathrm{kN}\right)$, the maximum normal stress $\left(\sigma_{l, \max }=0.056 \mathrm{MPa}\right)$ and the maximum tangential tension $\left(\tau_{0, \max }=0.037 \mathrm{MPa}\right)$.

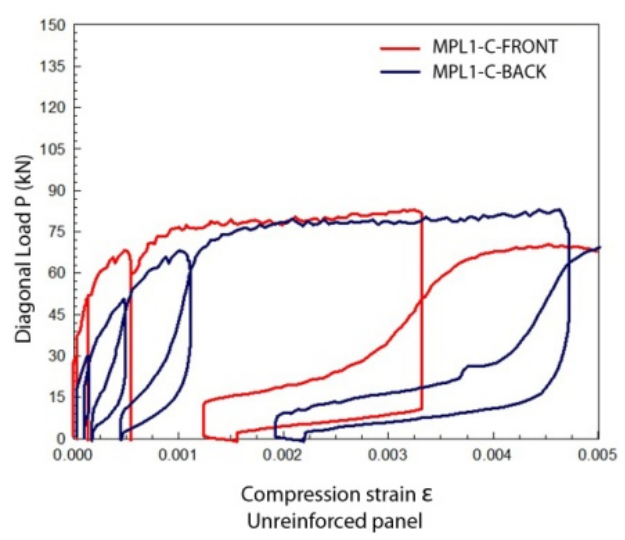

(a)

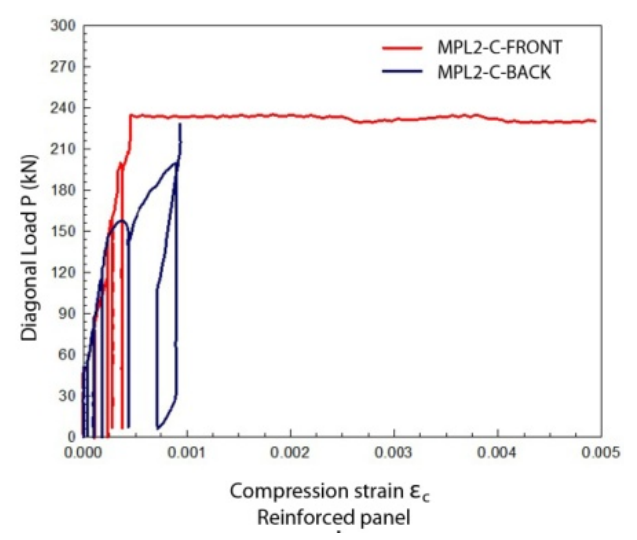

(b)

Figure 5. Diagram force-deformation compression of unreinforced (a) and reinforced (b) panel of the test. 
The curves shown in Figure 5 represent the load diagonal $P$ in the function of the average strain compression in the direction of the load $\varepsilon_{\mathrm{c}}$, measured on both faces of the panel.

Then there was a second test on samples that was reinforced by the application of FRP (the test was carried out in situ on 17 May 2013); shape and dimensions were similar to the previous case. During the test, the load-deformation diagram was plotted (Figure 5b); once again, at the conclusion of the load cycles, it was possible to evaluate the maximum load diagonal $\left(\mathrm{P}_{\max }=239.46 \mathrm{kN}\right)$, the maximum normal stress $\left(\sigma_{1, \max }=0162 \mathrm{MPa}\right)$ and the maximum tangential tension $\left(\tau_{0, \max }=0.108 \mathrm{MPa}\right)$ (Table 1).

Table 1. Mechanical characteristics of unreinforced and reinforced panels.

\begin{tabular}{ccccc}
\hline & Condition & \multicolumn{3}{c}{ Results } \\
\cline { 3 - 5 } & & $\mathbf{P}_{\mathbf{m a x}}(\mathbf{k N})$ & $\boldsymbol{\sigma}_{\mathbf{1 , \text { max }}}(\mathbf{M p a})$ & $\boldsymbol{\tau}_{\mathbf{0}} \mathbf{( M p a )}$ \\
\hline Lava stone & Unreinforced & 83.10 & 0.056 & 0.037 \\
masonry & Reinforced with FRP & 239.46 & 0.162 & 0.108 \\
\hline
\end{tabular}

With regard to the mortar, the laboratory analysis showed good resistance both to compression $\left(\sigma_{\mathrm{c}}=5.2 \mathrm{~N} / \mathrm{mm}^{2}\right)$ and tension strength $\left(\mathrm{f}_{\mathrm{ct}}=0.64 \mathrm{~N} / \mathrm{mm}^{2}\right)$, and normal values for Young's modulus $\left(E_{\mathrm{m}}=5332 \mathrm{~N} / \mathrm{mm}^{2}\right)$ and Poisson's coefficient $(0.17)$ (Table 2).

Table 2. Mechanical characteristics of the mortar used for the reinforcement.

\begin{tabular}{ccccc}
\hline \multirow{2}{*}{ Results of Tests } & $\boldsymbol{\sigma}_{\mathbf{c}}\left(\mathbf{N} / \mathbf{m m}^{2}\right)$ & $\mathbf{f}_{\mathbf{c t}}\left(\mathbf{N} / \mathbf{m m}^{2}\right)$ & $\mathbf{E}_{\mathbf{m}}\left(\mathbf{N} / \mathbf{m m}^{\mathbf{2}}\right)$ & Coeff. Poisson \\
\cline { 2 - 4 } & $\mathbf{5 . 2}$ & $\mathbf{0 . 6 4}$ & $\mathbf{5 3 3 2}$ & $\mathbf{0 . 1 7}$ \\
\hline TYPE & $\begin{array}{r}\text { Fiber-reinforced, thixotropic, shrinkage compensated, hydraulic lime mortar with } \\
\text { pozzolanic aggregates, conforming to the standards UNI EN 480-5 and UNI EN 459-1 }\end{array}$ \\
\hline COMPOSITION & \multicolumn{2}{c}{$\begin{array}{c}20 \% \text { Silica, alumina }(\mathrm{SxAyHz}) ; 10 \% \text { Calcium silicate }\left(\mathrm{Ca}_{2} \mathrm{SiO}_{4}\right) \\
\left.42 \% \text { Calcium hydroxide }(\mathrm{Ca}(\mathrm{OH}))_{2}\right) ; 28 \% \text { Calcium carbonate }\left(\mathrm{CaCO}_{3}\right)\end{array}$} \\
\hline
\end{tabular}

The most important aim of the test was to determine the efficiency of an innovative technique of reinforcement and seismic improvement for this type of wall, through the application of FRP materials. The experimental results reflect the building's strength of masonry before and after the intervention; the values of the maximum normal stress and maximum shear stress characteristic data are fundamental for the development of the building calculation model [7,32].

The obtained data show values in line with those derived from similar experiments carried out on other wall types (Table 3), as well as in line with those found in the scientific literature. 
Table 3. Mechanical characteristics of different types of masonry, for different techniques of consolidation [33].

\begin{tabular}{|c|c|c|c|c|c|c|}
\hline \multirow{2}{*}{ Building } & \multirow{2}{*}{ Masonry Type } & \multirow{2}{*}{ Condition } & \multicolumn{3}{|c|}{ Results } & \multirow{2}{*}{$\begin{array}{c}\text { Reinforce } \\
\text { Technology Type }\end{array}$} \\
\hline & & & $P_{\max }(k N)$ & $\sigma_{1, \max }(\mathrm{Mpa})$ & $\tau_{0}(\mathrm{Mpa})$ & \\
\hline \multirow{3}{*}{$\begin{array}{c}\text { Aquila, Italy. } \\
\text { Location: Porta } \\
\text { Napoli }\end{array}$} & \multirow{3}{*}{$\begin{array}{c}\text { White compact and just } \\
\text { hewn stones }\end{array}$} & Unreinforced & 44.51 & 0.039 & 0.026 & - \\
\hline & & Reinforced & 200.81 & 0.152 & 0.102 & 2 \\
\hline & & Reinforced & 184.47 & 0.139 & 0.092 & 3 \\
\hline \multirow{2}{*}{$\begin{array}{l}\text { Montefalco, Italy. } \\
\text { Location: Turrita }\end{array}$} & \multirow{2}{*}{$\begin{array}{c}\text { Double layer masonry } \\
\text { of just hewn stones } \\
\text { (pink limestone) }\end{array}$} & Unreinforced & - & 0.029 & 0.019 & - \\
\hline & & Reinforced & - & 0.066 & 0.044 & 4 \\
\hline \multirow{3}{*}{$\begin{array}{l}\text { Foligno, Italy. } \\
\text { Location: Pale }\end{array}$} & \multirow{3}{*}{$\begin{array}{l}\text { Double layer masonry } \\
\text { of just hewn stones } \\
\text { (white limestone) }\end{array}$} & Unreinforced & - & 0.017 & 0.011 & - \\
\hline & & Reinforced & - & 0.044 & 0.029 & 5 \\
\hline & & Reinforced & - & 0.027 & 0.018 & 6 \\
\hline \multirow{4}{*}{$\begin{array}{c}\text { Trevi, Italy. } \\
\text { Location: Trevi's } \\
\text { Shop }\end{array}$} & \multirow{4}{*}{$\begin{array}{l}\text { Double layer masonry } \\
\text { of just hewn stones } \\
\text { (pink limestone) }\end{array}$} & Unreinforced & - & 0.035 & 0.023 & - \\
\hline & & Reinforced & - & 0.063 & 0.042 & 1 \\
\hline & & Reinforced & - & 0.071 & 0.047 & 4 \\
\hline & & Reinforced & - & 0.039 & 0.026 & 6 \\
\hline \multirow{2}{*}{$\begin{array}{l}\text { Foligno, Italy. } \\
\text { Location: } \\
\text { ex-Hospital }\end{array}$} & \multirow{2}{*}{$\begin{array}{l}\text { Double layer masonry } \\
\text { of just hewn stones } \\
\text { (pink limestone) }\end{array}$} & Unreinforced & - & 0.033 & 0.022 & - \\
\hline & & Reinforced & - & 0.089 & 0.059 & 5 \\
\hline
\end{tabular}

Notes: 1 Reinforced with FRP grid; 2 Reinforced with FRP grid, masonry wall in good condition; 3 Reinforced with FRP grid, damaged masonry wall; 4 Reinforced with FRP tapes, 5 Reinforced with the "Reticolatus" method; 6 Reinforced by replacing the joints mortar with a better one.

\section{Conclusions}

Composite materials have a growing use in the field of construction. Among them, fiber-reinforced polymers (FPR) offer considerable support in the performance of existing buildings. FPRs' lightness, oxidation resistance and compatibility with lime mortars make it possible to achieve the reinforcement of plasters to be used in stonework consolidation.

The recent renovation works carried out on a prominent building in the historic center of Catania (Sicily, Italy) provided the opportunity to quantify the increase in resistance of the lava stone masonries, consolidated with fiber mesh-reinforced plaster. The tests showed a three-fold increase of the diagonal compression that determines the break in the wall panel that was reinforced compared to the original one. Therefore, the results of the study lead to the conclusion that the consolidation technique with FRP materials is particularly valid for the purposes of increasing the resistance peak, in addition to having a good response to stresses, thanks to the increase of the equivalent principal tension of the traction. These results represent an advancement of knowledge because FPR nets had not yet been tested on lava stone masonry, and therefore they add to the literature related to experiments based on different kind of masonries.

Acknowledgments: Thanks to Edoardo Boscarino and Andrea Pitrone, designers and construction managers in Asylum Sant'Agata works; Carlisi Valentina; the "Fibre Net" S.r.l.

Author Contributions: The authors contributed equally to this work.

Conflicts of Interest: The authors declare no conflict of interest.

\section{References}

1. Porto, S.M.C.; Leanza, P.M.; Cascone, G. Developing interpretation plans to promote traditional rural buildings as Built Heritage Attractions. Int. J. Tour. Res. 2011, 14, 421-436. [CrossRef]

2. Porto, S.M.C.; Cascone, G. A building characterization-based method for the advancement of knowledge on external architectural features of traditional rural buildings. Inf. Constr. 2013, 65, 481-496. 
3. Borri, A.; De Maria, A. Eurocode 8 and Italian Code. A comparison about safety levels and classification of interventions on masonry existing buildings. In Eurocode 8 Perspectives from the Italian Standpoint Workshop; Doppiavoce: Neaples, Italy, 2009; pp. 237-246.

4. Giuffrè, A. Monumenti e Terremoti; Multigrafica Editrice: Rome, Italy, 1988.

5. Giuffrè, A. Studi e interventi sull'edilizia storica. In Ingegneria Antisismica; Gavarini, C., Giuffrè, A., Longhi, G., Eds.; ESA: Milan, Italy, 1991.

6. Giuffrè, A. Sicurezza e Conservazione dei Centri Storici; Laterza: Rome, Italy, 1993.

7. Arcidiacono, C.; Porto, S.M.C.; Cascone, G. Seismic Analysis of Traditional Stone Rural Buildings: Case study of a one-storey building. Inf. Constr. 2015, 67, 481-496. [CrossRef]

8. Doglioni, F.; Petrini, V.; Moretti, A. Le Chiese e Il Terremoto; LINT: Trieste, Italy, 1994.

9. Doglioni, F. Codice di Pratica (Linee Guida) per la progettazione degli interventi di riparazione, miglioramento sismico e restauro dei Beni Architettonici danneggiati dal terremoto umbro-marchigiano del 1997; Bollettino Ufficiale Regione Marche: Ancona, Italy, 2000.

10. Ministry of Heritage and Cultural Activities and Tourism. Linee Guida per la Valutazione e Riduzione del Rischio Sismico del Patrimonio Culturale Allineate alle Nuove Norme Tecniche per le Costruzioni (d.m. 14 Gennaio 2008); Ministry of Heritage and Cultural Activities and Tourism: Rome, Italy, 2008.

11. Zanello, E. Rinforzo Strutturale e Principi Della Conservazione: Un Esempio Applicativo su Edifici in Tufo Soggetti a Vincolo. Available online: http://www.ingenio-web.it/Notizia/4821/Rinforzo_strutturale: _un_esempio_applicativo_su_edifici_in_tufo_soggetti_a_vincolo.html (accessed on 12 April 2016).

12. Borri, A.; Corradi, M.; Vignoli, A. Seismic upgrading of masonry structures with FRP. In Proceedings of the 7th International Conference on "Inspection Appraisal Repairs and Maintenance of Buildings and Structures", Nottingham, UK, 11-13 September 2001.

13. Pearson, M.; Donchev, T.; Limbachiya, M. An investigation into the sustainability of FRP reinforcement bars. In Proceedings of the Fourth International Conference on Durability and Sustainability of Fiber-Reinforced Polymer (FRP) Composites for Construction and Rehabilitation, Quebec, QC, Canada, 20-22 July 2011.

14. GangaRao, H.; Ruifeng, L. Advanced fiber reinforced polymer composites for sustainable civil infrastructures. Available online: http://www.civil.ist.utl.pt/ cristina/RREst/Aulas_Apresentacoes / 07_Bibliografia/construcao $\% 20$ terra $\% 20 \% 28$ earth $\% 20$ construction $\% 29 / 5 \% 20 F I N A L \% 20$ hota_paper_keynote. pdf (accessed on 12 April 2016).

15. Liberatore, D. Progetto Catania: Indagine Sulla Risposta Sismica di Due Edifici in Muratura; CNR-Gruppo Nazionale per la Difesa dai Terremoti: Rome, Italy, 2000.

16. Leanza, P.; Porto, S.; Sapienza, V.; Cascone, S. A heritage interpretation-based itinerary to enhance tourist use of traditional rural buildings. Sustainability 2016, 8, 1-19. [CrossRef]

17. Lee, L.; Estrada, H. Composite primer. In The International Handbook of FRP Composites in Civil Engineering; CRC Press: Boca Raton, FL, USA, 2013.

18. Credali, L. L'impiego Delle Tecnologie FRP Nel Recupero Strutturale di Edifici Storici. Available online: http://www.betontex.it/wp-content/uploads/2015/01/Articolo-Convegno-Alba_20.02.08.pdf (accessed on 12 April 2016).

19. Keller, T. Utilizzo Mirato di Compositi in FRP in Edilizia e Nella Costruzione di Ponti; Istituto Federale Svizzero di Tecnologia: Losanna, Italy, 2014; Available online: http://www.betontex.it/wpcontent/uploads/2015/01/Articolo-Convegno-Alba_20.02.08.pdf (accessed on 12 April 2016).

20. Jain, R.; Lee, L. Fiber reinforced polymer (FRP) composites for infrastructure applications: Focusing on innovation. In Technology Implementation and Sustainability; Springer Science \& Business Media: New York, NY, USA, 2012.

21. AVK-Federation of Reinforced Plastics. Sustainability of Fibre-Reinforced Plastics: An Assessment Based on Selected Examples of Application; AVK Report; AVK: Frankfurt am Main, Germany, 2010.

22. Motavalli, M. Externally bonded FRP composite system for rehabilitation. In The International Handbook of FRP Composites in Civil Engineering; CRC Press: Boca Raton, FL, USA, 2013.

23. Bakis, C.; Bank, L.; Brown, V.; Cosenza, E.; Davalos, J.; Lesko, J.; Machida, A.; Rizkalla, S.; Triantafillou, T. Fiber-reinforced polymer composites for construction-State-of-the-art review. J. Compos. Constr. 2012, 6, 73-87. [CrossRef]

24. Hamed, E.; Chang, Z.; Rabinovitch, O. Strengthening of reinforced concrete arches with externally bonded composite materials: Testing and analysis. J. Compos. Constr. 2014, 6, 73-87. [CrossRef] 
25. Carmelo e Salvatore Sciuto-Patti, Archivi di Architettura Tra '800 e '900, Exhibition, Cured by Cultural Heritage of Catania. 2015. Available online: http://www.regione.sicilia.it/beniculturali/dirbenicult/ areariservata/eventi/eventipubblicati/reportEventi.asp?cod=2779 (accessed on 12 April 2016).

26. Sapienza, V. Residenze in Villa a Catania, tra Ottocento e Novecento; Il Lunario: Enna, Italy, 2004.

27. Comite Europeen de Normalisation (CEN). ENV 1998-1 Eurocode 8: Design of Structures for Earthquake Resistance. Part 1: General Rules, Seismic Actions and Rules for Buildings; Comite Europeen de Normalisation: Brussels, Belgium, 2004.

28. Binda, L.; Penazzi, D.; Mirabella Roberti, G.; Baronio, G.; Tedeschi, C.; Tiraboschi, C. Indagini per la caratterizzazione dei materiali. In Proceedings of the 9th National Congress on "L'ingegneria sismica in Italia", Turin, Italy, 20-23 October 1999.

29. Borri, A.; Corradi, M.; Vignoli, A. Il problema della valutazione della resistenza a taglio della muratura mediante prove sperimentali. In Proceedings of the X National Congress "L'Ingegneria Sismica in Italia", Potenza-Matera, Italy, 9-13 September 2001.

30. Sapienza, V. Le murature tradizionali nell'area etnea: Modi costruttivi e consistenza materica. Recuper. Conserv. 2008, 84, 46-51.

31. Margani, L. Le Murature Antiche e Principi di Forma, Geometria, Decorazione, Costruzione, Stabilità; Lussografica: Caltanissetta, Italy, 2013. (In Italian)

32. Mas Guindal, A. La concepción estructural de la fábrica en la arquitectura. Inf. Constr. 2005, 56, 3-12. [CrossRef]

33. De Maria, A.; Donà, C.; Borri, A. Manuale delle Murature Storiche; DEI: Rome, Italy, 2011. (In Italian)

(C) 2016 by the authors; licensee MDPI, Basel, Switzerland. This article is an open access article distributed under the terms and conditions of the Creative Commons Attribution (CC-BY) license (http://creativecommons.org/licenses/by/4.0/). 